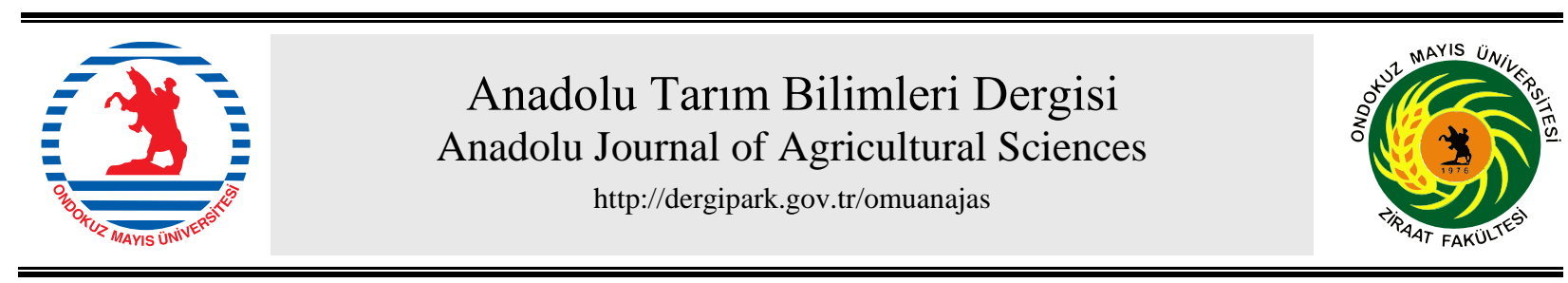

Araştırma/Research

Anadolu Tarım Bilim. Derg./Anadolu J Agr Sci, 36 (2021)

ISSN: 1308-8750 (Print) 1308-8769 (Online)

doi: 10.6171/omuanajas.872885

\title{
Chemical Content and Quality of Sun Cured Tobacco Lines
}

\author{
๑Ahmet Kinay ${ }^{\mathrm{a}}$, ๑Dursun Kurt ${ }^{\mathrm{b}}$ \\ ${ }^{a}$ Department of Field Crops, Faculty of Agriculture, Tokat Gaziosmanpasa University, Tokat, Turkey \\ ${ }^{b}$ Department of Plant and Animal Production, Bafra Vocational High School, Ondokuz Mayis University, Samsun, Turkey \\ *Sorumlu yazar/corresponding author: dursun.kurt@omu.edu.tr \\ Geliș/Received 02/02/2021 Kabul/Accepted 02/05/2021
}

\begin{abstract}
Tobacco (Nicotiana tabacum L.) is a plant grown for leaves. Leaves are dried and fermented to use in tobacco products. Oriental tobacco is widely consumed in the world due to its good aroma qualities. For this, different chemical and quality properties of Oriental tobacco lines, which have undergone small changes over time, have been examined. The samples (27 lines and 1 variety (Xanthi 2A)) obtained from tobacco lines grown in three different locations (Bagpinar, Evciler and Yenice) in Tokat and Canakkale were used in this study. Quality index, nicotine, glucose, fructose, chlorogenic acid and rutin amounts were determined to investigate the effect of geographical environment on tobacco lines. Chemical analyzes were performed using high performance liquid chromatography. The data obtained from the chromatographic analyzes and quality index were evaluated by using principal component analysis. These three different locations were generally separated and clustered. Due to its geographical locations, genotypes better adapted in the Bagpinar location.
\end{abstract}

\section{Güneşte Kurutulmuş Tütünlerin Kimyasal İçeriği ve Kalitesi}

\section{ÖZET}

Tütün (Nicotiana tabacum L.), yaprakları için yetiştirilen bir bitkidir. Yaprakları tütün ürünlerinde kullanılmak üzere kurutularak fermente edilmektedir. Oryantal tütün, yüksek aroma kalitesinden dolayı dünyada yaygın olarak tüketilmektedir.Bunun için, zamanla varyasyon gösteren oryantal tütün hatlarının farklı kimyasal ve kalite özellikleri incelenmiştir. Bu çalışmada, Tokat ve Çanakkale'de üç farklı lokasyonda (Bağpınar, Evciler ve Yenice) yetiştirilen tütün hatlarından elde edilen örnekler (27 hat ve 1 çeşit (Xanthi 2A)) kullanılmıştır. Coğrafi çevrenin tütün hatları üzerindeki etkisini araştırmak için kalite indeksi, nikotin, glikoz, fruktoz, klorojenik asit ve rutin miktarları belirlenmiştir. Kimyasal analizler, yüksek performanslı sıvı kromatografisi kullanılarak yapılmıştır. Kromatografik analizlerden ve kalite indeksinden elde edilen veriler, temel bileşen analizi kullanılarak değerlendirilmiş, üç farklı konum genel olarak ayrılmış ve kümelenmiştir. Genotipler, coğrafi konumu nedeniyle Bağpınar lokasyonuna daha iyi adaptasyon sağlamıştır.

Keywords: HPLC Nicotine Oriental PCA Phenolics Sugars

Anahtar Sözcükler:

Fenolikler

Nikotin

Oryantal

Şekerler

Temel bileşen analizi

YBSK

(c) OMU ANAJAS 2021

\section{Introduction}

Nicotiana species known to be the most widely used tobacco plants as drug plants in the world (Chase et al., 2003; Knapp et al., 2004). Oriental tobaccos (Turkish tobaccos) are recuperative to blend-type cigarette blends, which are widely consumed in the world because of their good aroma qualities (Ekren, 2018; Kurt and Yilmaz, 2018).

Tobacco is a plant grown for leaves. Leaves are dried, fermented, and used in tobacco products. Nicotine ((S)-3(1-methyl-2-pyrrolidinyl) pyridine) is the most common among the alkaloids find in tobacco (NIH DrugFacts, 
2018). Alkaloids are compounds known for their direct effect on tobacco quality and availability (Andersen et al., 1991) and cause widespread use of tobacco products worldwide because of nicotine can be addiction (NIH Drugfacts, 2018; Xia et al., 2014). Other tobacco alkaloids are nornicotine, anabasine and anatabine, which has less effect as pharmacologically (Clark et al., 1965). In the tobacco industry, nicotine analysis is very important for both quality control and understanding of secondary and defense metabolism (Lu and Ralapati, 1998; Gaquerel et al., 2009). In tobacco leaf, nicotine and other alkaloids are measured by different techniques. Gas and liquid chromatographic methods are the most frequently used and continuously developed methods in determination of alkaloids in the tobacco. Nicotine and other minor alkaloids have been quantified in tobacco plants using gas chromatography (GC) (Yang et al., 2002; Sheng et al., 2005; Hossain and Salehuddin, 2013) and high performance liquid chromatography (HPLC) (Manceau et al., 1992; Troje et al., 1997; Tambwekar et al., 2003; Vlase et al., 2005; Murray, 2014; Kinay, 2018; Kurt, 2021). HPLC is both an inexpensive and convenient method for the quantitative determination of nicotine in tobacco leaf (Tambwekar et al., 2003). In addition, nicotine is a water-soluble alkaloid, which is supply advantageous in the liquid chromatography analysis in terms of sensitivity and accuracy.

Sugars are the main constituents of tobacco leaves. Sugar composition is directly related to the taste and smell of tobacco. Flue-cured and Sun-cured tobacco are known to contain abundant glucose, fructose and sucrose (Troje et al., 1997; Leffingwell, 1999). Glucose and fructose are the most important in soluble sugars and are called reducing sugars. It is generally accepted that leaves with high reducing sugar content have a better smoking. Therefore, it is necessary to reliably identify sugars in leaf tobacco identification (Pang et al., 2006). The determination of sugar can be done by spectrophotometric method which can differentiate total sugar and total reducing sugar. The sum of glucose, fructose, sucrose, xylose and maltose represents $82 \%$ of the total sugar content (Troje et al., 1997). Sugars have been quantified in tobacco plants using spectrophotometric (Lindsay, 1973), colorimetric (Rodriguez-Sevilla et al., 1999), thin-layer chromatography (Han and Robyt, 1998), gas chromatography methods (Adams et al., 1999; Silva and Ferraz, 2004). However, for the rapid characterization of sugars, HPLC was preferred. Analysis by HPLC with refractive index detector (RID) is the most common method used in the detection of sugars (Troje et al., 1997; Chavez-Servin et al., 2004; Pang et al., 2006; Kinay, 2018; Kurt, 2021).

Studies have shown that the main polyphenols in tobacco are chlorogenic acid, rutin and scopoletin (Bazinet et al., 2005) and their combustion products are considered to be carcinogens (Roe et al., 1959). For this reason, the separation of polyphenols and determination of their amounts in tobacco has gained importance in recent years. For the analysis of polyphenols in tobacco; GC or GC-MS (Li et al., 2009), chemiluminescence (Cui et al., 1999), ultraviolet (Chen et al., 2007; Gu et al., 2010) or MS (Wang et al., 2008) with HPLC, capillary electrophesis (Jiang et al., 2004) and molecular identification (Ji et al., 2013) methods can be used (Xie et al., 2011; Ji et al., 2013). Among these methods, spectrophotometric method is generally prefer for determination of total polyphenol. GC or HPLC are the most powerful method for others analytes in the tobacco.

In this study, oriental tobacco have been optimized by a fast, convenient and practical reverse-phase HPLC-DAD method to determine the nicotine, chlorogenic acid and rutin content and HPLC-RID method sugars content (as glucose and fructose) in the tobacco leaves. Nicotine, glucose, fructose, chlorogenic acid and rutin amounts of oriental tobacco were determined by this method. Quality grade index was determined by American grade system (Kurt, 2021). All the results were evaluated by using principal component analysis (PCA). Similarities and differences of the genotypes according to the locations are presented. Thus, the effect of the factors on chemical content and physical quality have been seen. As far as we know, there will be first results for Turkish oriental tobacco.

\section{Material and Methods}

\subsection{Chemicals}

Standard, reagents and chemicals were obtained from Sigma and Merck and they are either chromatographic or analytical grade. Millipore ultrapure water (Type I) was used for all analysis.

\subsection{Sampling}

Republic of Turkey Tobacco and Alcohol Market Regulatory Authority (TAPDK) supported by "Determination of Lines with Superior Characteristics in Tokat Region Basma Type Tobaccos” in 2015 as part of the project vegetation during the field trip in plant height, flowering period, number of leaves, leaf genotypes, which are found to be different in terms of their properties, are provided by bagging. The geographical coordinates of the 27 lines are given in Table 1. Basma tobacco is most grown at the Erbaa (Tokat) and Yenice (Canakkale). Therefore, the samples were selected from these locations. Genotypes collected along with maturation of the seeds were subjected 
to DNA Fingerprint analysis in early 2016 and their affinities were determined. After these analyzes, 27 lines, which were found to be different in terms of genetic structure, and 1 standard (Xanthi 2A) in 2016, were included in the

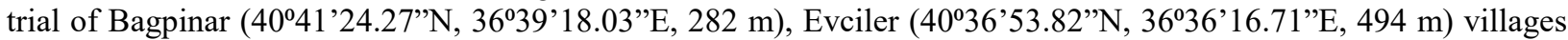

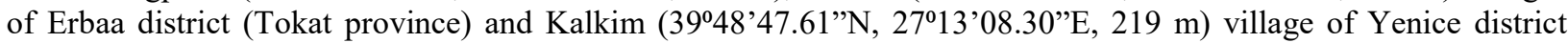
(Canakkale province).

Table 1. Geographical coordinates of 27 lines

Çizelge 1. 27 hattın coğrafi koordinatlart

\begin{tabular}{|c|c|c|c|c|c|c|c|c|c|}
\hline Code & Village & Altitude & Longitude & Latitude & Code & Village & Altitude & Longitude & Latitude \\
\hline Erb3 & Esencay & 558 & $40^{\circ} 40^{\prime} 20.03^{\prime \prime}$ & $36^{0} 22^{\prime} 19.17^{\prime \prime}$ & Erb19 & Evciler & 629 & $40^{\circ} 36^{\prime} 21.82^{\prime \prime}$ & $36^{0} 36^{\prime} 57.71^{\prime \prime}$ \\
\hline Erb5 & Tanoba & 554 & $40^{\circ} 38^{\prime} 53.84$ ' & 36024'15.17'" & Erb21 & Endikpinar & 628 & $40^{\circ} 36 ’ 20.96 "$ & $36^{0} 37^{\prime} 17.13^{\prime \prime}$ \\
\hline Erb6 & Tanoba & 561 & $40^{\circ} 38^{\prime} 54.93 "$ & 36024'10.96" & Erb23 & Endikpinar & 609 & $40^{\circ} 36^{\prime} 16.66^{\prime \prime}$ & $36^{0} 37^{\prime} 43.65^{\prime \prime}$ \\
\hline Erb7 & Tanoba & 515 & 40³9'28.98" & $36^{\circ} 24^{\prime} 23.44^{\prime \prime}$ & Erb25 & Kupluce & 593 & $40^{\circ} 35^{\prime} 57.59^{\prime \prime}$ & $36^{0} 38^{\prime} 24.03^{\prime \prime}$ \\
\hline Erb9 & Karaagac & 596 & $40^{\circ} 41^{\prime} 14.10^{\prime \prime}$ & 36²4'25.39”' & Erb26 & Kupluce & 582 & $40^{\circ} 35^{\prime} 53.79^{\prime \prime}$ & $36^{\circ} 38^{\prime} 34.30^{\prime \prime}$ \\
\hline Erb10 & Karaagac & 594 & $40^{\circ} 41^{\prime} 13.69$ ' & $36^{\circ} 24^{\prime} 59.08^{\prime \prime}$ & Erb27 & Cakir & 535 & $40^{\circ} 37^{\prime} 25.59^{\prime \prime}$ & 36039'29.89" \\
\hline Erb11 & Akca & 421 & $40^{\circ} 41 ' 55.99 "$ & $36^{\circ} 26^{\prime} 54.01^{\prime \prime}$ & Erb28 & Cakir & 544 & $40^{\circ} 37^{\prime} 16.70^{\prime \prime}$ & $36^{03} 39^{\prime} 41.51^{\prime \prime}$ \\
\hline Erb12 & Akca & 347 & $40^{\circ} 42^{\prime} 24.21^{\prime \prime}$ & $36^{\circ} 27^{\prime} 20.10^{\prime \prime}$ & Erb30 & Erbaa & 242 & $40^{\circ} 40^{\prime} 06.24^{\prime \prime}$ & $36^{0} 34^{\prime} 55.36^{\prime \prime}$ \\
\hline Erb13 & Aydinsofu & 577 & $40^{\circ} 36^{\prime} 16.44^{\prime \prime}$ & $36^{0} 35^{\prime} 06.14^{\prime \prime}$ & Erb32 & Karayaka & 291 & $40^{\circ} 44^{\prime} 33.97 "$ & $36^{03} 3^{\prime} 51.47^{\prime \prime}$ \\
\hline Erb14 & Aydinsofu & 551 & $40^{\circ} 36^{\prime} 23.47^{\prime \prime}$ & $36^{0} 35^{\prime} 06.72^{\prime \prime}$ & Erb34 & Karayaka & 327 & $40^{\circ} 44^{\prime} 26.15^{\prime \prime}$ & $36^{\circ} 35^{\prime} 30.57^{\prime \prime}$ \\
\hline Erb15 & Aydinsofu & 564 & $40^{\circ} 36^{\prime} 25.47^{\prime \prime}$ & $36^{0} 35^{\prime} 17.80^{\prime \prime}$ & Erb35 & Karayaka & 299 & $40^{\circ} 44^{\prime} 07.25^{\prime \prime}$ & $36^{03} 5^{\prime} 42.46^{\prime \prime}$ \\
\hline Erb16 & Aydinsofu & 541 & $40^{\circ} 36^{\prime} 28.78^{\prime \prime}$ & $36^{0} 35^{\prime} 11.34^{\prime \prime}$ & Erb36 & Uzumlu & 330 & $40^{\circ} 43^{\prime} 01.25^{\prime \prime}$ & $36^{\circ} 39^{\prime} 12.80^{\prime \prime}$ \\
\hline Erb17 & Evciler & 520 & $40^{\circ} 36^{\prime} 39.27^{\prime \prime}$ & $36^{\circ} 36^{\prime} 13.38^{\prime \prime}$ & Erb38 & Uzumlu & 323 & $40^{\circ} 42^{\prime} 43.30^{\prime \prime}$ & $36^{03} 9^{\prime} 27.75^{\prime \prime}$ \\
\hline Erb18 & Evciler & 567 & $40^{\circ} 36^{\prime} 29.30^{\prime \prime}$ & $36^{0} 36^{\prime} 21.81^{\prime \prime}$ & \multicolumn{2}{|c|}{ Xanthi 2A } & \multicolumn{3}{|c|}{ Basma registered variety } \\
\hline
\end{tabular}

Seedlings belonging to the genotypes were grown in the peat environment, in the viols, in the float system. Experiments were established as tusing randomize complete block design with three replicates. Each plot is composed of 4 rows of $5 \mathrm{~m}$ lenght, planting at distances of $45^{*} 10 \mathrm{~cm}$. Between the plots $1 \mathrm{~m}$ and $50 \mathrm{~cm}$ edge effects at the ends of the leaves were left, harvesting operations were completed in 3 quarters. Leaves arranged manually were dried in the sun. The leaf tobacco, which completed the drying process, analysed according to American Grade System, which called Quality Grade Index (QGI), by tobacco technological experts. Tobacco samples were kept in the oven at $80^{\circ} \mathrm{C}$ for 24 hours and then milled to $0.2 \mathrm{~mm}$ diameter for chemical analysis.

\subsection{Chromatographic Methods for Analytes}

To optimize the chromatographic conditions, column screening, flow rate, column temperature and different mobile phases studies were experienced. Wavelengths were selected according to detector response for all compounds. The mobile phase system is preferred with a water and acetonitrile system considering the peak response and resolution. In order to achieve a robust chromatographic separation, important analytical parameters, including retention time, peak response, and mobile phase were optimized by altering the column temperature and flow rate.

\subsubsection{Nicotine}

Nicotine (NIC) was analyzed on an Agilent HPLC equipped with diode-array detector (DAD). The chromatographic separations were achieved on an ACE 5 AQ C18 column $(250 \mathrm{~mm}$ length, $4.6 \mathrm{~mm}$ ID with $5 \mu \mathrm{m}$ particle size). The mobile phase, consisting of a mixture of water which consist $0.1 \%$ acetic acid and acetonitrile (85:15, v/v), had a flow rate of $1.00 \mathrm{~mL} / \mathrm{min}$ as isocratic elution. The detector wavelength was set at $324 \mathrm{~nm}$ for nicotine. The injection volume was $20.0 \mu \mathrm{L}$ and the column temperature was maintained at $35^{\circ} \mathrm{C}$. Seven injections were performed to obtain absorption plots for concentrations ranging from 0.1 to $10.0 \%$. Solutions for the linearity test were prepared by diluting the mixed standard stock solutions to the desired level.

Samples were prepared by weighing approximately $200 \mathrm{mg}$ of tobacco into a $20 \mathrm{ml}$ tubes, adding $18 \mathrm{ml}$ of water (consist $0.1 \%$ acetic acid) and $2 \mathrm{~mL}$ acetonitrile followed by 15 minutes of sonication in ultrasonic bath and then centrifuged at $3000 \mathrm{rpm}$ for 10 minutes. Supernatant was filtered with $0.45 \mu \mathrm{m}$ Nylon filter to the vials for the injection.

\subsubsection{Glucose and fructose}


Determination of glucose (GLU) and fructose (FRU) were performed with Agilent HPLC equipped with refractive index detector (DAD) and Zorbax Carbohydrate column $(4.6 * 250 \mathrm{~mm})$. The mobile phase was acetonitrile:water (75:25, v:v). The mobile phase was pumped at a flow rate of $1.5 \mathrm{~mL} / \mathrm{min}$ and the column temperature was adjusted $40^{\circ} \mathrm{C}$. Typically, $20 \mu \mathrm{L}$ of sample solution was injected. Calibration curve was obtained from $0.1 \%-25.0 \%$ ranging. Samples were prepared by weighing approximately $1.00 \mathrm{~g}$ of tobacco into a $25 \mathrm{ml}$ tubes, adding $20 \mathrm{~mL}$ of water (consist $0.1 \%$ acetic acid) and $5 \mathrm{~mL}$ methanol followed by 30 minutes of sonication in ultrasonic bath and then centrifuged at $3000 \mathrm{rpm}$ for 10 minutes. Supernatant was filtered with $0.45 \mu \mathrm{m}$ Nylon filter to the vials for the injection.

\subsubsection{Chlorogenic acid and rutin}

Chromatographic separation and quantification of chlorogenic acid (CHL) and rutin (RTN) were performed on an Agilent HPLC equipped with diode-array detector (DAD) and an Agilent InfinityLab Poroshell 120 EC-C18 column $(3 * 150 \mathrm{~mm})$. The mobile phase system consisted of $1 \%$ acetic acid in water $(\mathrm{A})$ and acetonitrile (B) using a isocritical elution with $85 \% \mathrm{~A}$ and $15 \% \mathrm{~B}$. The flow rate was $0.3 \mathrm{~mL} / \mathrm{min}$, and the temperature of the column was maintained at $35^{\circ} \mathrm{C}$. $324 \mathrm{~nm}$ was selected for analytes. Injection volume was $5 \mu \mathrm{L}$.

Samples were prepared by weighing approximately $200 \mathrm{mg}$ of tobacco into a $25 \mathrm{ml}$ tubes, adding $6 \mathrm{~mL}$ of water (consist $5 \%$ acetic acid) and $4 \mathrm{~mL}$ methanol followed by 30 minutes of sonication in ultrasonic bath and then centrifuged at $3000 \mathrm{rpm}$ for 10 minutes. Supernatant was filtered with $0.45 \mu \mathrm{m}$ Nylon filter to the vials for the injection.

\section{Results and Discussion}

Classification of tobacco samples from different locations were carried out using chemometric methods, the multivariate analyses were performed by using MINITAB 15 Statistical Software. Scores visualize results of Principal Component Analysis (PCA) (Ward's algorithmic method) and loading plots. Data for PCA and sample chromatograms, which was obtained from chromatographic analyses, were given at the SM-Table 1, SM-Fig. 1, 2 and 3. L3 (Yenice) for Canakkale and L1 (Bagpinar) and L2 (Evciler) for Tokat abbreviations were used for the locations, respectively. Tobacco samples with different location characteristics were evaluated in terms of nicotine, glucose, fructose, glucose+fructose, chlorogenic acid, rutin, chlorogenic acid+rutin and quality grade index.

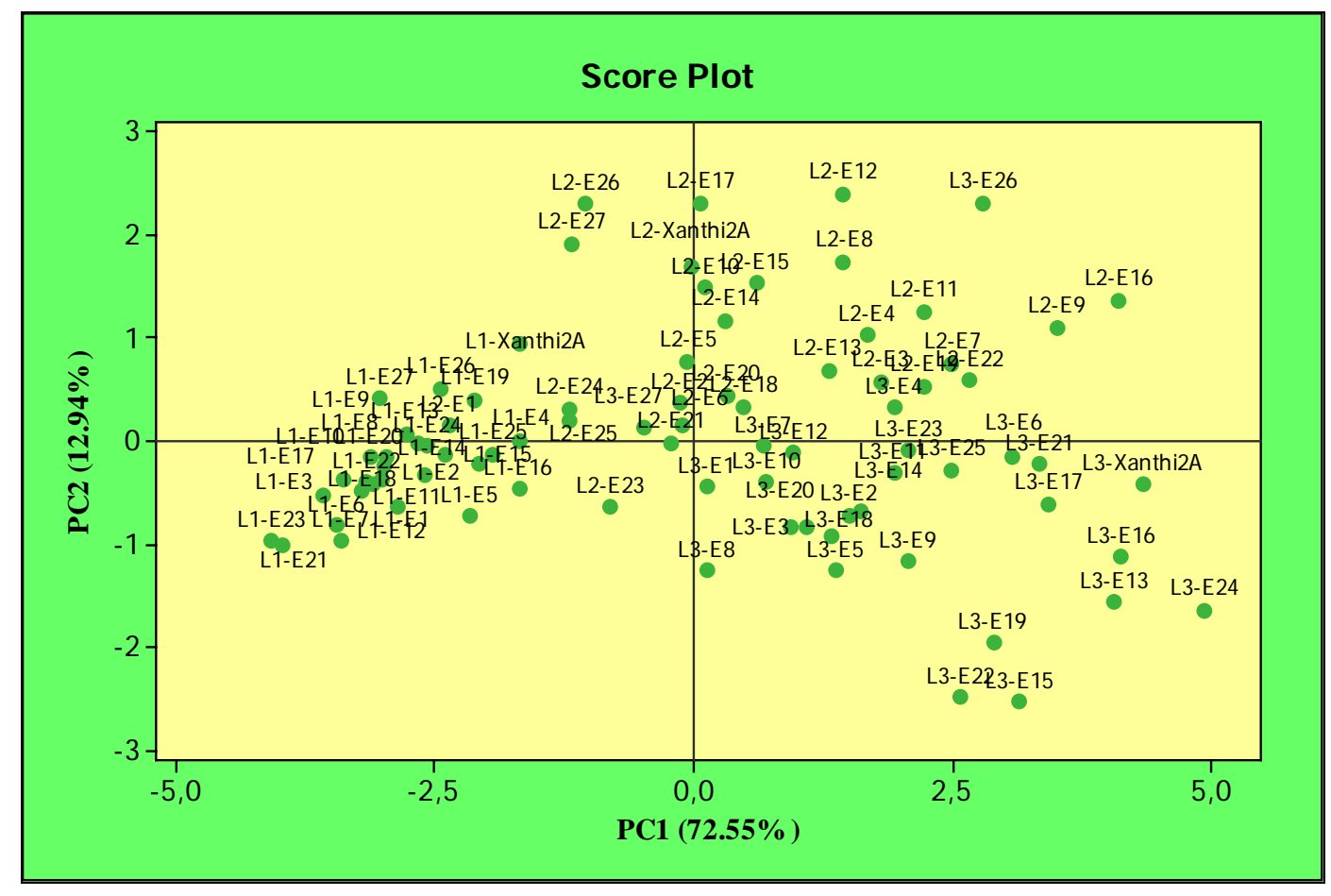

Figure 1. Score Plot of PCA for L1, L2 and L3

Şekil 1. L1, L2 ve L3 için PCA skor grafiği 
As it can be seen in the Figure 1, three main groups was obtained from the score plot of analytes was indicated according to PC1 and PC2. L1 locations had been formed a group, the other locations had been formed another group according to PC2. PC1 are most effective variety for the separate L1 locations than others. On the other hand, PC2 was played important role on L2 and L3 locations. L1-Xanthi 2A, L2-Xanthi 2A and L3-Xanthi 2A are clustered with their same location samples. Although, positive effect of PC1 and PC2 were seen on the L1-Xanthi 2A and L2-Xanthi 2A, L3-Xanthi 2A has been negatively affected from PC2. L1 locations were clearly separated and accumulated while L2 and L3 locations were separated and distributed other locations.

PC1 has $72.55 \%$ effect on the separation of locations while PC2 has a $12.94 \%$ effect. PC1 play an important role for clustering locations especially on the L1 samples. L2-E23, L2-E24, L2-E25, L3-E27 samples were shown similarity with L1 samples. L2 locations has positive effect of PC1 and PC2. L3 location has negative effect of PC1 and PC2. L2 and L3 were grouped under the PC1.

When the PCA was accomplished, the results of the modelling power analysis show that nicotine was the more effective variables to distinctive the tobacco samples on the L2 location, as regards to the loading plot in Figure 2. In addition to, L3 location has been affected from other components.

CHL, FRU, GLU, GLU+FRU are important parameters for separating L3 locations. QGI, CHL+RTN and RTN have effect on the L2 locations. Clustering of L1 and L2 was realized under the effect of NIC.

The tobacco lines which used in this study has small changes from Xanthi 2A variety. The samples were clustered together with the Xanthi 2A considered as control for each location. This has been explained the similarities of the samples with control sample of Xanthi 2A. Xanthi 2A was cultivated in these regions since 2002; therefore, these clustering and similarities are expected for each locations lines. These similarities are clearly seen in the score graph which obtained PCA. The score plot was showed the clustering of the L1 location have been better. Because, the production of these lines are very intensive in the L1 locations. This show that tobacco lines of L1 location has very good adaptation.

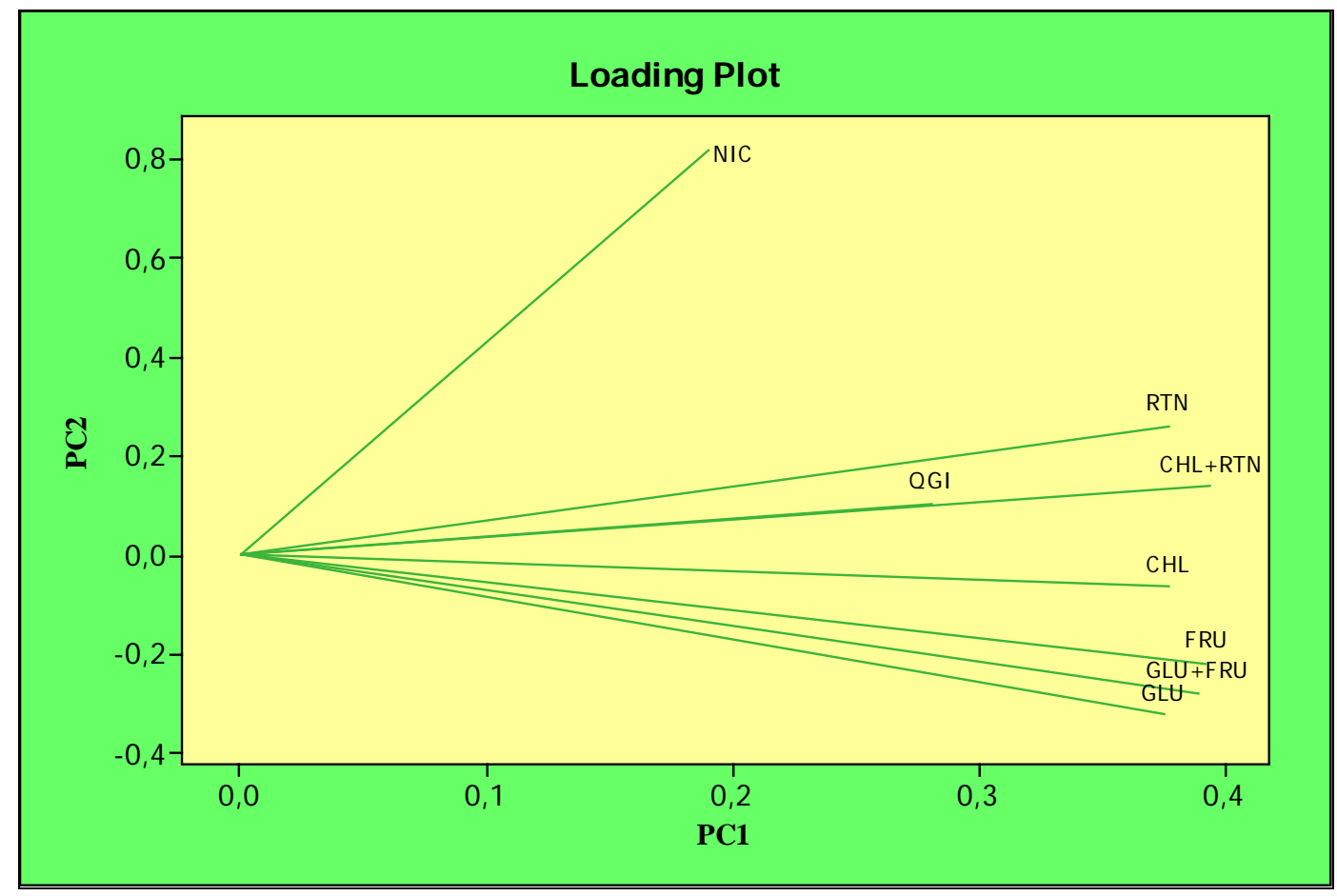

Figure 2. Loading Plot of PCA for L1, L2 and L3

Şekil 2. L1, L2 ve L3 için PCA ăgırlık grafiği

In some lines L2 and L3 locations have shown similarity to other locations and clustering with other locations which means that the adaptation process continues in L2 and L3 locations. Compared to other locations, the best environmental conditions are the L3 location. Since the force, rainfall and strength of the land structure is the best region, tobacco has a different growth trend in this region. L1 was the weakest location of the study and therefore all genotypes had showed similar results.

Quality grade index values varied between 30.19 and $81.52 \%$ and the greatest performance at 3 locations was obtained from the Erb21 line. Nicotine demands of leaf-tobacco buying companies vary between 2.2-2.7\% (Kinay et 
al., 2019). Although present nicotine contents varied between $0.59-3.34 \%$, average nicotine contents (1.62\%) were below these demanded values. Such a deficiency can be eliminated with nitrogenous fertilizers (Lourenco et al., 2000; Karaivazoglou et al., 2006) and planting density (Bilalis et al., 2015). A similar case is also valid for glucose, fructose and reduced sugar and markets usually demand parallel values with nicotine or demand high sugar contents. Glucose, fructose and reduced sugar (glucose+fructose) contents varied respectively between 1.06-14.92\%, 1.51$11.29 \%$ and $2.71-25.30 \%$. Present sugar contents were generally within desired values, but they can easily be improved with various agricultural practices. Besides nicotine and reduced sugars, designating taste and smoking characteristics, secondary metabolites directly effective in color, taste and aroma should also be taken into consideration in product design and formation processes. Of these secondary metabolites, polyphenols are the most significant ones and chlorogenic acid and rutin are the most common polyphenols in tobaccos (Wang et al., 2008). Xie et al. (2011) investigated chlorogenic acid and rutin contents of oriental tobaccos in China and reported these values respectively as $1560 \mathrm{ppm}$ and $4240 \mathrm{ppm}$. In present study, chlorogenic acid contents varied between 54.16 and $704.50 \mathrm{ppm}$, rutin contents varied between 177.13 and $1164.57 \mathrm{ppm}$ and total of these two polyphenols varied between 231.29 and $1658.90 \mathrm{ppm}$. Tobaccos are quite sensitive to genetic and environmental factors, thus present polyphenol contents were generally lower than the earlier reports (Wang et al., 2008; Xie et al., 2011; Ji et al., 2013).

\section{Conclusion}

Principal component analysis was performed by analyzing the results of QGI and NIC, GLU, GLU, CHL, RTN analysis of Bagpinar (L1), Evciler (L2) and Yenice (L3) from Oriental tobacco lines. It has been observed that all lines are clustered according to locations. According to the PCA score charts, L2 and L3 locations in the L1 location outside the L1 location in the same location, all lines are clustered. The lines in all locations are clustered in the same location with the control Xanthi 2A which is cultivated in that area. Since all of these lines have similar genetics with Xanthi 2A, an expected result was confirmed by PCA. Furthermore, the fact that more production is performed at L1 location has shown that this location is better adapted to Xanthi 2A. As production increased, similarities and differences were observed to be higher. However, more precise measurements were made by chromatographic analyzes and separate results were obtained for each parameter. This resulted in a clearer appearance of the similarities and differences of the lines. Geographical location, production and chemical analysis were used together to reveal the relationships between tobacco genotypes.

\section{Supplementary Material}

Supplementary material related to this article can be found, in the online version.

\section{Acknowledgements}

This study was supported by Republic of Turkey Tobacco and Alcohol Market Regulatory Authority (Project name: Determination of Lines with Superior Characteristics in Tokat Region Basmas Type Tobaccos). The authors are grateful to Dr. Z. Pinar Gumus (Central Research Testing and Analysis Laboratory Research and Application Center EGE-MATAL) for contribution.

\section{Declaration of Interest}

No potential conflict of interest is reported by the authors.

\begin{tabular}{clll}
\multicolumn{2}{c}{ Abbreviations } & & \\
GC & Gas chromatography & HPLC & High performance liquid chromatography \\
RID & Refractive index detector & DAD & Diode-array detector \\
PCA & Principal component analysis & QGI & Quality Grade Index \\
NIC & Nicotine & GLU & Glucose \\
FRU & Fructose & CHL & Chlorogenic acid \\
RTN & Rutin & &
\end{tabular}

\section{References}

Adams, M.A., Chen, Z.L., Landman, P., Colmer, T.D., 1999. Simultaneous determination by capillary gas chromatography of organic acids, sugars, and sugar alcohols in plant tissue extracts as their trimethylsilyl derivatives. Analytical Biochemistry, 266 (1): 77-84. 
Andersen, R.A., Fleming, P.D., Burton, H.R., Hamilton-Kemp, T.R., Sutton, T.G., 1991. Nitrosated, acylated, and oxidized pyridine alkaloids during storage of smokeless tobaccos: effects of moisture, temperature, and their interactions. Journal of Agricultural and Food Chemistry, 39: 1280-1287.

Bazinet, L., De Grandpre Y., Porter, A., 2005. Enhanced tobacco polyphenol electromigration and impact on membrane integrity. Journal of Membrane Science, 254 (1-2): 111-118.

Bilalis, D.J., Travlos, I.S., Portugal, J., Tsioros, S., Papastylianou, Y., Papatheohari, Y., Avgoulas, C., Tabaxi, I., Alexopoulou, E., Kanatas, P.J. 2015. Narrow row spacing yield and decreased nicotine content in sun-cured tobacco (Nicotiana tabacum L.). Industrial Crops and Products 75: 212-215.

Chase, M.W., Knapp, S., Cox, A.V., Clarkson, J.J., Butsko, Y., Joseph, J., Savolainen, V., Parokonny, A.S., 2003. Molecular systematics, GISH and the origin of hybrid taxa in Nicotiana (Solanaceae). Ann. Bot., 92: 107-127.

Chavez-Servin, J.L., Castellote, A.I., Lopez-Sabater, M.C., 2004. Analysis of mono- and di-saccharides in milkbased formulae by high-performance liquid chromatography with refractive index detection. Journal of Chromatography A, 1043 (2): 211-216.

Chen, Y., Yu, Q.J., Li, X., Luo, Y., Liu, H., 2007. Extraction and HPLC characterization of chlorogenic acid from tobacco residuals. Separation Science and Technology, 42 (15): 3481-3492.

Clark, M.S.G., Rand, M.J., Vanov, S., 1965. Comparison of pharmacological activity of nicotine and related alkaloids occurring in cigarette smoke. Archives Internationales de Pharmacodynamie et de Thérapie, 156: 363379.

Cui, H., He, C., Zhao, G., 1999. Determination of polyphenols by high-performance liquid chromatography with inhibited chemiluminescence detection. Journal of Chromatography A, 855 (1): 171-179.

Ekren, S., 2018. The examination of the chemical compounds of Aegean region tobacco leaves at different priming stages in Turkey. Fresenius Environ. Bulletin, 27: 313-319.

Gaquerel, E., Weinhold, A., Baldwin, I., 2009. Molecular interactions between the specialist herbivore Manduca sexta (Lepidoptera, Sphigidae) and its natural host Nicotiana attenuata. VIII. An unbiased GCxGC-ToFMS Analysis of the plant's elicited volatile emissions. Plant. Physiol. 149: 1408-1423.

Gu, J., Zeng, X., Kong, B., Mao, Y., Liu W., Wei, W., 2010. Rapid determination of polyphenols in tobacco by MLC. Chromatographia, 71(9-10): 769-774.

Han, N.S. and Robyt, J.F., 1998. Separation and detection of sugars and alditols on thin layer chromatograms. Carbohydrate Research, 313(2): 135-137.

Hossain, A.M., Salehuddin, S.M., 2013. Analytical determination of nicotine in tobacco leaves by gas chromatography-mass spectrometry. Arabian J. Chem., 6(3): 275-278.

Ji, X., Wei, Y., Liu, G., Chen, H., 2013. Quantitative determination of polyphenols in tobacco leaves by HPLC. Journal of Food, Agriculture \& Environment, 11(1): 868-870.

Jiang, H., He, Y., Zhao, H., Hu, Y., 2004. Determination of chlorogenic acid and rutin in cigarettes by an improved capillary electrophoresis indirect chemiluminescence system. Analytica Chimica Acta, 512(1): 111-119.

Karaivazoglou, N.A., Tsotsolis, N.C., Tsadilas, C.D., 2006. Influence of liming and form of nitrogen fertilizer on nutrient uptake, growth, yield and quality of virginia (flue-cured) tobacco. Field Crops Research, 100: 52-60.

Knapp, S., Chase, M.W., Clarkson, J.J., 2004. Nomenclatural changes and a new sectional classification in Nicotiana (Solanaceae). Taxon, 53: 73-82.

Kinay, A., Kurt, D., Karakoc, E., 2019. Yield and quality performances of hybrid tobacco developed for Gümüşhacıköy Basma region. Turkish Journal of Agriculture - Food Science and Technology, 7(sp2): 1-6.

Kinay, A., 2018. Effects of cadmium on nicotine, reducing sugar and phenolic contents of Basma tobacco variety. Fresenius Environ. Bulletin, 27: 9195-9202.

Kurt, D., Yilmaz, G., 2018. Hand groups oriented yield and grade index characters of oriental tobaccos. Anadolu J Agr Sci., 33: 254-260.

Kurt, D., 2021. Impacts of environmental variations on quality and chemical contents of oriental tobacco. Contributions to Tobacco Research, 30: xxx-xxx.

Leffingwell, J.C., 1999. Leaf chemistry: basic chemical constituents of tobacco leaf and differences among tobacco types. In Tobacco: Production Chemistry and Technology; Davis, D. L., Nielsen, M. T., Eds.; Blackwell Science: Oxford, U.K., pp 265-284.

Li, F., Liu, Q., Cai, W., Shao, X.G., 2009. Analysis of scopoletin and caffeic acid in tobacco by gc-ms after a rapid derivatization procedure. Chromatographia, 69 (7-8): 743-748.

Lindsay, H., 1973. A Clorimetric Estimation of Reducing Sugars in Potatoes. Potato Research, 16: 176-179.

Lourenco, M.G., Ferrao, J.M., Figueiredo, E.L., Amaro, J.A., Rocha, M.E., 2000. Effects of N fertilization and antioxidant application on alkaloit concentration of flue-cured tobacco. Tropical Agriculture, 77(2): 93-98.

Lu, G.H., Ralapati, S., 1998. Application of high-performance capillary electrophoresis to the quantitative analysis of nicotine and profiling of other alkaloids in ATF-regulated tobacco products. Electrophoresis, 19: 19-26. 
Manceau, F., Fliniaux, M.A., Jacquin-Dubreuil, A., 1992. A high performance liquid chromatographic procedure for the analysis of tobacco alkaloids: application to the evaluation of tobacco alkaloids in plants and cell suspension cultures. Phytochem Anal., 3: 65-68.

Murray, J.L., 2014. Nicotine and what else?: HPLC elution optimization for the analysis of alkaloids found in electronic cigarettes, in: Honors Theses, University of Tennessee at Chattanooga, TN.

NIH, DrugFacts, 2018. National Institute on Drug Abuse (NIH), https://www.drugabuse.gov/publications/drugfacts/cigarettes-other-tobacco-products (03.06.2020).

Pang, T., Bai, C., Xu, Y., Xu, G., Yuan, Z., Su, Y., Peng, L., 2006. Determination of sugars in tobacco leaf by hplc with evaporative light scattering detection. Journal of Liquid Chromatography \& Related Technologies, 29(9): 1281-1289.

Rodriguez-Sevilla, M.D., Villanueva-Sua'rez, M.J., Redondo-Cuenca, A., 1999. Effects of processing conditions on soluble sugars content of carrot, beetroot and turnip. Food Chemistry, 66(1): 81-85.

Roe, F.J.C., Salaman, M.H., Cohen, J., 1959. Incomplete carcinogens in cigarette smoke condensate: tumourpromotion by a phenolic fraction. British Journal of Cancer, 13: 623-633.

Sheng, L.Q., Ding, L., Tong, H.W., Yong, G.P., Zhou, X.Z., Liu, S.M., 2005. Determination of nicotine-related alkaloids in tobacco and cigarette smoke by GC-FID. Chromatographia, 62: 63-68.

Silva, F.O., Ferraz, V., 2004. Microwave-assisted preparation of sugars and organic acids for simultaneous determination in citric fruits by gas chromatography. Food Chemistry, 88(4): 609-612.

Tambwekar, K.R., Kakariya, R.B., Garg, S. A., 2003. Validated high performance liquid chromatographic method for analysis of nicotine in pure form and from formulations. J. Pharm. Biomed. Anal., 32: 441-450.

Troje, S. Z., Fröbe, Z., Perović, Đ., 1997. Analysis of selected alkaloids and sugars in tobacco extract. Journal of Chromatography A, 775: 101-107.

Vlase, L., Filip, L., Mindrutau, I., Leucuta, S.E., 2005. Determination of nicotine from tobacco by LC- MS-MS. Stud. Unive. Babes-Bolyai Phys. L, (4b): 19-24.

Wang, H.Y., Zhao, M.M., Yang, B., Jiang, Y.M., Rao, G.H., 2008. Identification of polyphenols in tobacco leaf and their antioxidant and antimicrobial activities. Food Chemistry, 107: 1399-1406.

Xia, B., Feng, M., Xu, G., Xu, J., Li, S., Chen, X., Ding, L., Zhou, Y., 2014. Investigation of the chemical compositions in tobacco of different origins and maturities at harvest by GC-MS and HPLC-PDA-QTOF-MS. Journal of Agricultural and Food Chemistry, 62: 4979-4987.

Xie, F., Yu, A., Hou, D., Liu, H., Ding, L., Zhang, S., 2011. Rapid and sensitive analysis of eight polyphenols in tobacco by rapid resolution liquid chromatogarphy. American Journal of Analytical Chemistry, 2: 929-933.

Yang, S., Smetena, I., Huang, C., 2002. Determination of tobacco alkaloids by gas chromatography with nitrogenphosphorus detection. Anal. Bioanal. Chem. 373: 839-843. 
SM-Table 1. Data for PCA

\begin{tabular}{|c|c|c|c|c|c|c|c|c|}
\hline LOC-ERB & QGI (\%) & NIC (\%) & GLU (\%) & FRU (\%) & GLU+FRU (\%) & CHL (ppm) & RTN (ppm) & CHL+RTN (ppm) \\
\hline L1-E1 & 54.37 & 1.12 & 1.59 & 1.78 & 3.36 & 139.00 & 283.80 & 422.80 \\
\hline L1-E2 & 61.03 & 0.92 & 1.48 & 2.00 & 3.48 & 152.33 & 355.41 & 507.74 \\
\hline L1-E3 & 43.96 & 0.93 & 1.38 & 1.67 & 3.06 & 80.26 & 275.49 & 355.75 \\
\hline L1-E4 & 58.36 & 1.11 & 1.94 & 2.66 & 4.60 & 223.15 & 511.12 & 734.27 \\
\hline L1-E5 & 47.90 & 0.94 & 2.63 & 3.27 & 5.90 & 240.16 & 346.84 & 587.00 \\
\hline L1-E6 & 55.64 & 0.69 & 1.37 & 1.81 & 3.18 & 86.38 & 235.72 & 322.10 \\
\hline L1-E7 & 35.73 & 0.72 & 2.69 & 1.86 & 4.55 & 86.56 & 326.32 & 412.88 \\
\hline L1-E9 & 61.34 & 1.28 & 1.43 & 2.19 & 3.62 & 159.48 & 276.17 & 435.65 \\
\hline L1-E10 & 44.07 & 0.90 & 1.51 & 1.59 & 3.10 & 138.57 & 328.37 & 466.95 \\
\hline L1-E11 & 57.59 & 0.99 & 1.53 & 1.88 & 3.41 & 119.82 & 285.71 & 405.53 \\
\hline L1-E12 & 57.43 & 1.01 & 2.43 & 2.87 & 5.30 & 92.22 & 258.59 & 350.80 \\
\hline L1-E13 & 42.58 & 1.43 & 1.42 & 2.45 & 3.87 & 171.45 & 338.78 & 510.23 \\
\hline L1-E14 & 47.74 & 1.15 & 1.29 & 1.83 & 3.12 & 284.51 & 352.14 & 636.65 \\
\hline L1-E15 & 57.37 & 1.02 & 1.78 & 2.21 & 4.00 & 247.10 & 395.98 & 643.08 \\
\hline L1-E16 & 68.16 & 0.83 & 3.18 & 1.73 & 4.91 & 243.66 & 420.01 & 663.67 \\
\hline L1-E18 & 51.32 & 0.92 & 1.35 & 1.67 & 3.02 & 136.00 & 312.97 & 448.97 \\
\hline L1-E19 & 47.53 & 1.43 & 1.27 & 1.96 & 3.23 & 250.38 & 461.81 & 712.19 \\
\hline L1-E20 & 35.38 & 1.17 & 1.69 & 1.59 & 3.27 & 136.75 & 387.46 & 524.21 \\
\hline L1-E21 & 51.33 & 0.59 & 1.08 & 1.63 & 2.71 & 54.16 & 177.13 & 231.29 \\
\hline L1-E22 & 37.51 & 0.94 & 1.29 & 1.73 & 3.03 & 146.64 & 384.33 & 530.97 \\
\hline L1-E23 & 30.19 & 0.73 & 1.13 & 1.70 & 2.83 & 103.29 & 219.46 & 322.75 \\
\hline L1-E24 & 46.79 & 1.15 & 1.06 & 1.73 & 2.78 & 241.99 & 375.34 & 617.33 \\
\hline L1-E25 & 57.84 & 1.09 & 2.31 & 1.83 & 4.15 & 252.10 & 419.93 & 672.03 \\
\hline L1-E26 & 61.99 & 1.73 & 1.14 & 2.95 & 4.09 & 143.09 & 290.19 & 433.27 \\
\hline L1-E27 & 51.42 & 1.63 & 1.55 & 1.51 & 3.06 & 118.00 & 288.43 & 406.43 \\
\hline L1-Xa.2A & 47.11 & 1.75 & 1.25 & 2.17 & 3.42 & 252.60 & 568.47 & 821.07 \\
\hline L2-E1 & 43.52 & 1.46 & 1.87 & 3.05 & 4.92 & 154.07 & 431.72 & 585.79 \\
\hline L2-E2 & 60.55 & 1.54 & 3.39 & 5.10 & 8.49 & 259.91 & 687.03 & 946.94 \\
\hline L2-E3 & 65.95 & 2.27 & 6.96 & 8.13 & 15.09 & 345.41 & 730.20 & 1075.62 \\
\hline L2-E4 & 79.84 & 2.47 & 6.52 & 7.63 & 14.15 & 270.19 & 714.02 & 984.20 \\
\hline L2-E7 & 65.58 & 2.28 & 7.48 & 8.10 & 15.58 & 392.50 & 875.99 & 1268.49 \\
\hline L2-E8 & 63.32 & 2.69 & 4.65 & 5.19 & 9.84 & 465.04 & 745.90 & 1210.94 \\
\hline L2-E9 & 77.74 & 2.69 & 8.58 & 8.79 & 17.37 & 488.59 & 850.62 & 1339.21 \\
\hline L2-E10 & 57.36 & 2.56 & 4.15 & 4.85 & 9.00 & 268.57 & 659.35 & 927.92 \\
\hline L2-E11 & 65.47 & 2.72 & 7.25 & 7.61 & 14.86 & 382.54 & 799.30 & 1181.84 \\
\hline L2-E12 & 71.24 & 3.23 & 5.14 & 5.72 & 10.86 & 306.56 & 774.04 & 1080.60 \\
\hline L2-E13 & 65.60 & 2.50 & 7.52 & 7.66 & 15.18 & 269.28 & 636.48 & 905.76 \\
\hline L2-E14 & 56.95 & 2.78 & 6.24 & 5.55 & 11.79 & 293.37 & 512.85 & 806.22 \\
\hline L2-E15 & 76.24 & 3.04 & 6.41 & 6.21 & 12.61 & 208.90 & 498.27 & 707.17 \\
\hline L2-E16 & 75.53 & 2.37 & 7.67 & 8.49 & 16.16 & 494.33 & 1164.57 & 1658.90 \\
\hline L2-E17 & 38.52 & 3.34 & 3.96 & 5.06 & 9.02 & 304.24 & 665.07 & 969.31 \\
\hline L2-E18 & 64.73 & 1.46 & 3.38 & 5.44 & 8.82 & 353.75 & 726.72 & 1080.47 \\
\hline L2-E19 & 79.98 & 2.07 & 7.43 & 7.53 & 14.96 & 358.37 & 775.94 & 1134.30 \\
\hline L2-E20 & 60.25 & 1.81 & 5.08 & 5.39 & 10.47 & 275.88 & 684.93 & 960.81 \\
\hline L2-E21 & 57.73 & 1.49 & 4.62 & 4.59 & 9.21 & 323.55 & 570.66 & 894.20 \\
\hline L2-E22 & 64.68 & 2.20 & 8.48 & 8.22 & 16.70 & 363.10 & 921.71 & 1284.81 \\
\hline L2-E23 & 50.66 & 1.28 & 3.83 & 6.54 & 10.38 & 256.52 & 451.25 & 707.77 \\
\hline L2-E24 & 43.57 & 1.84 & 3.65 & 3.87 & 7.52 & 294.99 & 448.60 & 743.59 \\
\hline L2-E25 & 70.30 & 1.42 & 2.70 & 3.30 & 6.00 & 241.78 & 439.25 & 681.04 \\
\hline L2-E26 & 62.33 & 2.95 & 1.88 & 2.74 & 4.61 & 231.28 & 499.74 & 731.02 \\
\hline L2-E27 & 67.34 & 2.60 & 1.93 & 2.61 & 4.53 & 195.55 & 503.43 & 698.98 \\
\hline L2-Xa.2A & 74.87 & 2.26 & 2.60 & 3.19 & 5.79 & 286.00 & 676.13 & 962.13 \\
\hline L3-E1 & 55.29 & 1.52 & 5.83 & 6.56 & 12.40 & 306.52 & 529.91 & 836.43 \\
\hline L3-E2 & 60.26 & 1.32 & 6.97 & 8.37 & 15.34 & 373.89 & 707.97 & 1081.86 \\
\hline L3-E3 & 62.50 & 1.11 & 5.40 & 7.70 & 13.10 & 445.39 & 613.13 & 1058.52 \\
\hline L3-E4 & 63.52 & 2.00 & 6.51 & 8.15 & 14.66 & 405.93 & 762.79 & 1168.72 \\
\hline L3-E5 & 61.10 & 1.22 & 8.35 & 8.57 & 16.92 & 381.35 & 570.97 & 952.33 \\
\hline L3-E6 & 64.31 & 1.71 & 8.23 & 7.91 & 16.14 & 621.52 & 811.97 & 1433.50 \\
\hline L3-E7 & 75.05 & 1.39 & 5.05 & 6.55 & 11.60 & 244.34 & 697.97 & 942.30 \\
\hline L3-E8 & 54.02 & 0.89 & 5.08 & 7.08 & 12.16 & 395.44 & 495.72 & 891.16 \\
\hline L3-E9 & 39.44 & 1.64 & 10.70 & 9.57 & 20.27 & 429.29 & 680.59 & 1109.88 \\
\hline L3-E10 & 37.07 & 1.68 & 6.29 & 7.78 & 14.07 & 383.98 & 650.66 & 1034.64 \\
\hline
\end{tabular}


Kinay and Kurt / Anadolu Tarım Bilim. Derg. / Anadolu J Agr Sci 36 (2021) 282-292

\begin{tabular}{|c|c|c|c|c|c|c|c|c|}
\hline L3-E14 & 71.95 & 1.70 & 7.81 & 9.16 & 16.98 & 386.00 & 506.97 & 892.98 \\
\hline L3-E15 & 79.00 & 0.93 & 14.49 & 10.34 & 24.84 & 428.36 & 544.07 & 972.43 \\
\hline L3-E16 & 79.44 & 1.58 & 12.47 & 10.35 & 22.83 & 559.04 & 746.11 & 1305.14 \\
\hline L3-E18 & 60.11 & 1.22 & 6.02 & 8.44 & 14.46 & 466.80 & 589.78 & 1056.58 \\
\hline L3-E19 & 71.30 & 1.28 & 12.63 & 11.29 & 23.92 & 385.68 & 583.08 & 968.76 \\
\hline L3-E20 & 52.05 & 1.30 & 6.95 & 8.15 & 15.11 & 323.73 & 668.39 & 992.13 \\
\hline L3-E22 & 58.67 & 0.86 & 13.59 & 10.66 & 24.25 & 328.16 & 676.18 & 1004.34 \\
\hline L3-E23 & 57.50 & 1.60 & 5.56 & 8.02 & 13.58 & 554.52 & 760.21 & 1314.73 \\
\hline L3-E24 & 76.40 & 1.28 & 13.62 & 10.77 & 24.39 & 704.50 & 794.87 & 1499.36 \\
\hline L3-E25 & 72.95 & 1.95 & 9.86 & 8.73 & 18.59 & 382.44 & 691.04 & 1073.48 \\
\hline L3-E26 & 60.00 & 3.09 & 5.85 & 6.60 & 12.45 & 481.03 & 1011.43 & 1492.46 \\
\hline L3-E27 & 61.36 & 1.45 & 3.55 & 5.06 & 8.61 & 220.57 & 618.18 & 838.75 \\
\hline L3-Xa.2A & 75.65 & 1.60 & 10.32 & 10.16 & 20.49 & 556.44 & 985.90 & 1542.34 \\
\hline
\end{tabular}

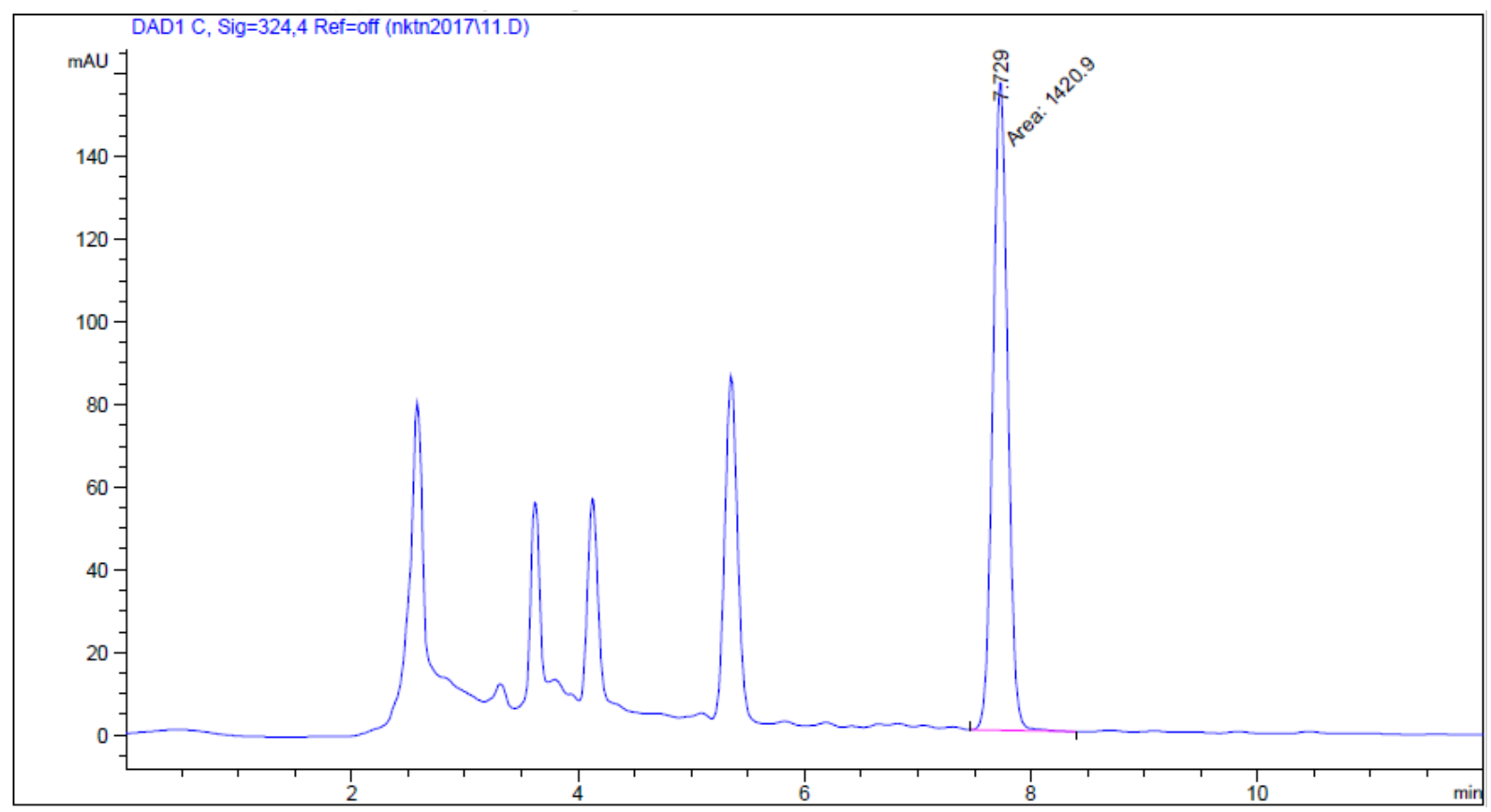

SM-Fig. 1. Sample chromatogram for nicotine 


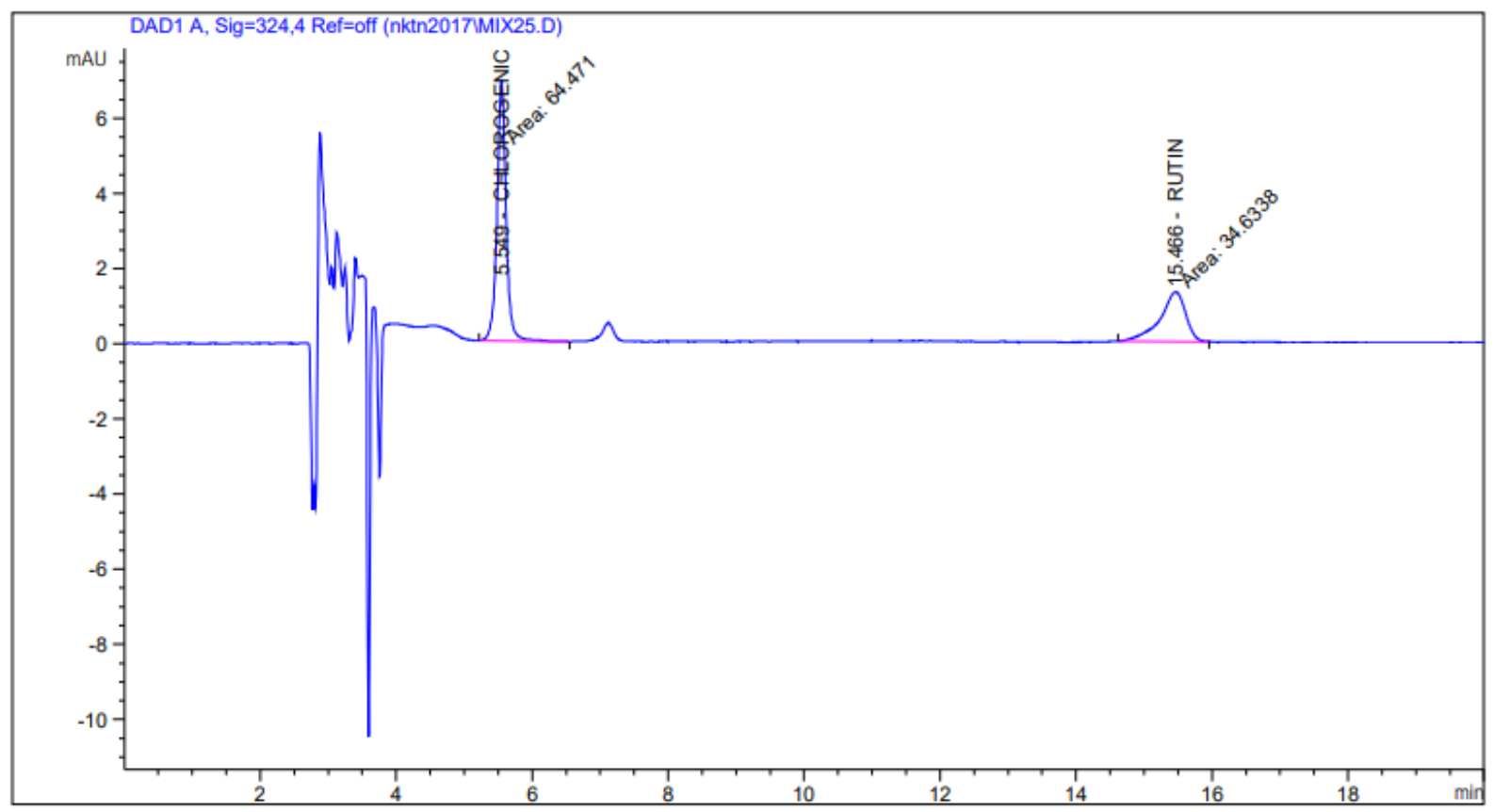

SM-Fig. 2. Sample chromatogram for chlorogenic acid and rutin

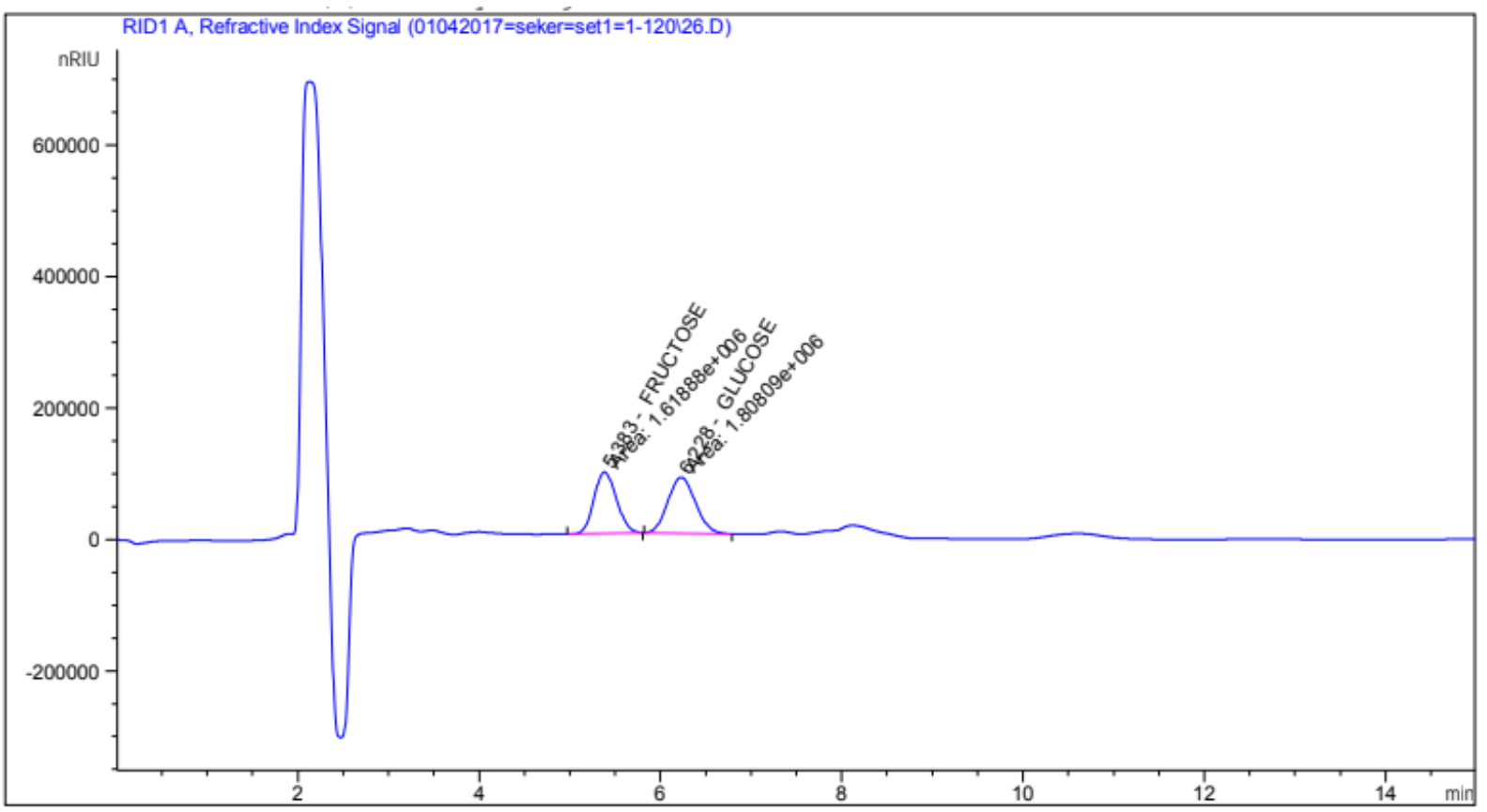

SM-Fig. 3. Sample chromatogram for glucose and fructose 